\title{
Small Intestinal Diffuse Large B-Cell Lymphoma
}

National Cancer Institute

\section{Source}

National Cancer Institute. Small Intestinal Diffuse Large B-Cell Lymphoma. NCI

Thesaurus. Code C96055.

A diffuse large B-cell lymphoma that arises from the small intestine. 